\title{
The Use Of Used Oil From Treatment With Absorption and pyrolysis As A mixed of Diesel Oil To Performance Diesel Engine
}

\author{
Aris Palinggi \\ \{apapaling1@gmail.com\} \\ State Politecnic of Kupang
}

\begin{abstract}
An adsorption process is able to filter out solid objects in used oil such as dust, scrap metals and charcoal from burnings so that the color of used oil is not too dense even though it is still black. The pyrolysis process can improve the color of used oil so that it becomes clear yellow like new oil, even though it does not meet diesel engine fuel criteria. The mixture of used oil from the pyrolysis process with diesel fuel still meets the characteristics of diesel fuel because the results are close to the characteristics of diesel fuel. Research results show that the mixture of used oil in diesel engine fuel if used as fuel can save $10 \%$ of the fuel because the power and efficiency when compared with pure diesel fuel is almost the same, but the exhaust emissions are large if the percentage of used oil in fuel is increased
\end{abstract}

Keywords: used oil, absorption, pyrolisis, mixture, diesel, performance

\section{Introduction}

The search for alternative energy is carried out intensively to save the use of fuel oil, especially in transportation and existing conventional engines or to replace dependence on fossil fuels, including the use of gas fuels (BBG), bio-energy and fuel cells, but the amount of energy sources. This alternative is not comparable to the development of energy needs because of the progress of development. Various efforts and research have been carried out to save diesel fuel in diesel engines, including by using bio-diesel derived from plants such as castor oil mixed with diesel to save the use of diesel fuel, but economically this has not been encouraging because of the price of oil distance is more expensive than diesel because the process and source of raw materials are increasingly difficult. Aside from increasing fuel demand with industrial progress and development, the rest of industrial processes and machinery that cannot yet be properly handled is the amount of waste that continues to increase, including exhaust emissions and used oil. Specifically for used oil, total production in Indonesia is 700 million liters per year [1], some of which is made from fake oil or discarded so as to pollute the environment. The rest is reprocessed as new oil or used as fuel oil in small industries. Because oil is extracted from petroleum, it is a hydrocarbon compound that has an energy value and is flammable, so it is necessary to find a way to use oil that is used primarily as fuel. Utilization of used oil as fuel has been widely used by traditional fishermen who use used oil by mixing with diesel fuel and then used as fuel in ship engines or ships, in aluminum smelting and lime making [2]. The use of used oil as the latest fuel is to process used oil into fuel that is similar to gasoline or diesel with a particular process, but this process is very expensive because it uses several chemicals 
and expensive systems [3]. The process of adsorption and pyrolysis in used oil before it is mixed with diesel is intended to clean used oil from residues both metal and charcoal so as not to damage the engine, while the use of used diesel oil mixed in diesel engines aims to save diesel fuel without much reducing performance on the engine.

\section{Diesel Engine Fuel}

Diesel is an engine with a compression ignition system, therefore the fuel characteristics for a diesel engine must match the compression ignition. Characteristics of the fuel include: heating value, flash point, viscosity, specific gravity and cetane number. In diesel engines an important fuel characteristic is the high cetane number so that it knocking does not easily occur and has good lubricating properties [4]

\section{Utilization of Used Oil}

To use used oil as fuel, special treatment is needed in advance so that good characteristics can be obtained, especially the ignition and combustion temperature. Used lubricants can be used as fuel oil with the addition of sulfuric acid, clay and fuel oil. The purpose of adding sulfuric acid is to reduce olefin, aromatic and non-hydrocarbon compounds found in used lubricants. The addition of clay aims to precipitate impurities, absorb sulfur compounds and improve color. Utilization of used oil as fuel in diesel engines can be done after processing first by heating and adding catalysts [5]. According to Arpa used processed oil can be used with a percentage of $100 \%$ if it is processed by pyrolysis but this method requires high heating energy so the process is expensive [3].

Processes of used oil without pyrolysis and examination of the characteristics of used oil found that refined used oil is suitable as diesel engine fuel when mixed with pure diesel fuel, and at a certain percentage engine power can increase but if the used oil content continues to increase, the engine power will decrease because with increasing percentage of used oil in diesel fuel will reduce the calorific value of the fuel, increase the viscosity so that the fuel is difficult to flow and can't pull out properly when there is compression [6]. The most influential factor in decreasing engine power with an increase in used oil in diesel fuel is that the hydrocarbon chain in the used oil is long so that combustion becomes imperfect and increases emissions in exhaust gases. According to Purwono in Raharjo, used lubricating oil can be recycled and the results will be in the diesel fraction and the diesel oil industry (IDO) fraction and can also be used as engine oil after adding additives.[2]

\section{Used Oil Processing}

Used oil cannot be directly used as fuel on an engine because it contains a variety of nonflammable substances such as water, metals, sulfur and soot of fuel. To use used oil as fuel, several stages of processing are needed. According to the United States Department of Environmental Protection EPA [7], the stages of processing used oil to be used as fuel are:

1. Dehydration stage, where the oil is heated with hot air with a minimum temperature of 140 ${ }^{\circ} \mathrm{C}$ for several hours so that the liquid content in it can evaporate.

2. The chemical treatment stage, which is to provide solvents in used oil so that the content of substances that cannot be evaporated by heating can be dissolved, substances that cannot evaporate include metals, sulfur and other objects that come from combustion residues and the process in their use. The most important addition of this solvent is to bind the residue to the used oil so that it can separate from the oil so that the used oil has good characteristics to be used as fuel.

3. Mixing other chemicals to remove wax and color 
4. Precipitation of adsorption to separate fuel from non-hydrocarbons such as metal solutions, sulfur and the rest ofthe chemicals used.

\section{Diesel Engine Fuel Retrenchment}

The main factor that shows a fuel-efficient engine is the power produced remains but the fuel consumption falls, but there are also those who argue that if fuel consumption is fixed and the power increases, the engine is turned to saving mode. This saving can be seen from the specific fuel consumption (sfc) in the calculation results of engine operation, because the engine is said to be economical if the fuel heat can be utilized as much as possible to produce more power [9]. The way to save fuel on a diesel engine is very much among others by electrical treatment, additives, and fuel heating. This aims to improve combustion efficiency with more complete combustion. The most fuel saving done today is by adding other fuels at prices cheaper or renewable fuel. Adding used treatment oil to diesel fuel is used to save fuel because some of it has been replaced by used oil so that only a small amount of diesel is used. [10]

\section{Adsorption Process}

Adsorption process is the process of settling and filtering used oil with a filter that is able to bind non-hydrocarbon substances to used oil, such as dust and fine metals so that the oil is clean from dangerous solids. Materials commonly used are membranes, sand, gravel, coconut shell charcoal and others.

\section{Pyrolysis Process}

Pyrolysis is the process of decomposition of organic compounds by heating without oxygen or with little oxygen. Pyrolysis of used oil is only done to evaporate the liquid that is in the material so that the heating value increases [8]

\section{Diesel Engine Performance}

Diesel engine performance is related to the performance produced by a diesel engine that uses certain fuels. Engine performance benchmarks are usually seen from the power generated, fuel consumption and exhaust emissions. Engine performance is obtained by using the engine performance formula.

\section{Research Method}

The research method used was the Experimental Laboratory Method, which is done following the adsorption and pyrolysis processes, and then mixing the used oil with diesel fuel and using it as diesel engine fuel.

\section{Research Procedure}

\section{Adsorption Method}

The adsorption process uses a column of filters with a total of 4 columns. In each column there is a filter starting from the top column to the bottom of the filter assisted by gravity to go to the next filter as in Figure 1 below. 


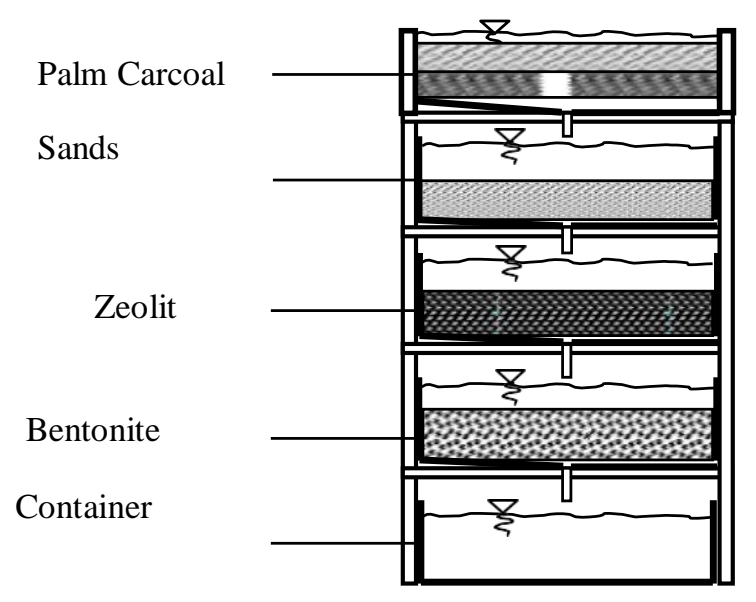

Figure 1. Adsorbent

\section{Pyrolysis Method}

Pyrolysis process is heating used oil at high temperatures in a state of little or no oxygen. Used oil will break into several parts such as liquids, gases and solid objects. Substances that have low boiling points will evaporate and go to pipes that have been cooled and function as condensers so that substances that evaporate will become liquid. Reactor pyrolysis can be seen in Figure 2 below.

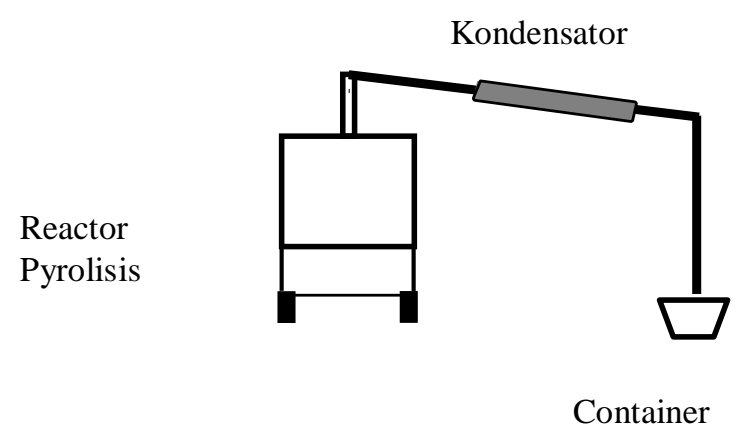

Figure 2. Reactor Pyrolisis

\section{The use of a mixture of used oil and Diesel Oil As Engine Fuel Diesel}

The fuel mixture used is 5\% used oil and $95 \%$ diesel fuel, $10 \%$ used oil and $90 \%$ diesel oil, $15 \%$ used oil and $85 \%$ diesel oil. This mixture is measured in weight ratio. After mixing, measurement of the characteristics of the mixture is carried out including the heating value, density and viscosity. Diesel engines that use throttle opening are set at 50\% and maximum engine speed is $2300 \mathrm{rpm}$. 


\section{Result and Discussion}

The measurement characteristics of used oil mixtures with diesel are presented in Table 1. After filtering by adsorption, the thickness of used oil is reduced due to a decrease in metal content, dust and charcoal. Then the pyrolysis process is carried out which results in a clear oil like new oil and a decrease in viscosity from $84.17 \mathrm{cSt}$ to $24.27 \mathrm{cSt}$. Then the mixture of used oil and diesel is mixed and measured the characteristics of the mixture and the result is the characteristics of used oil for the calorific value and specific gravity close to the characteristics of diesel fuel but the viscosity value is still very high. so it does not meet the diesel engine fuel characteristic criteria as in table 1 below.

Table 1. Caracteristic of Mixture

\begin{tabular}{|c|c|c|c|}
\hline Fuel Material & $\begin{array}{c}\text { Heating Value ( LHV ) } \\
\text { ( Calori/gram })\end{array}$ & $\begin{array}{c}\text { Viskosity } \\
(\mathbf{c S t}) \mathbf{4 0}\end{array}$ & $\begin{array}{c}\text { Density } \\
\text { ( gram/ml })\end{array}$ \\
\hline $\begin{array}{c}100 \% \text { Used Oil with } \\
\text { adsorption }\end{array}$ & 10630.155 & 84.17 & 0.867 \\
\hline $\begin{array}{c}100 \% \text { Used Oil with } \\
\text { Pyrolysis }\end{array}$ & 10650,111 & 24.27 & 0.861 \\
\hline $100 \%$ Diesel fuel & 10773.311 & 1.96 & 0.835 \\
\hline $5 \%$ Used Oil & 10769.456 & 2.5285 & 0.8364 \\
\hline $10 \%$ Used Oil & 10755.601 & 3.057 & 0.8379 \\
\hline $15 \%$ Used Oil & 10741.74 & 3.5995 & 0.8393 \\
\hline
\end{tabular}

The use of used oil as a mixture of diesel engine fuel does not really effect the engine power with the percentage of used oil in fuel of a maximum of $10 \%$. If it continues to be increased to $15 \%$ then the engine power starts to decrease. This is influenced by the high viscosity of the fuel mixture if the concentration of used oil in diesel engine fuel materials is more than $10 \%$ as depicted in the Figure 3. 


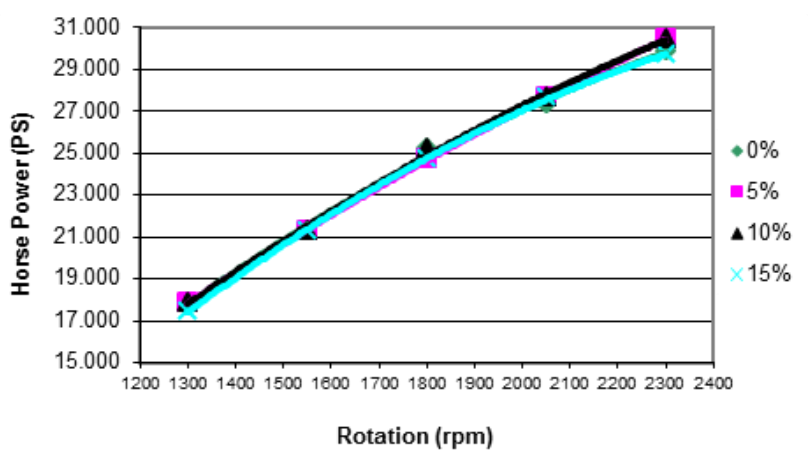

Figure 3. Effective Power

\section{Spesific Fuel Consumtion ( SFe )}

$\mathrm{SFc}$ is a comparison between the power produced and the amount of fuel used. By using used oil as a mixture of diesel engine fuel, Sfc increased slightly in the mixture of 5\% to $10 \%$ while in the mixture of $10 \%$ to $15 \%, \mathrm{SFc}$ decreased. This is caused by the effective power increasing in the mixture of 5 to $10 \%$ and decreasing in the mixture of 10 to $15 \%$ due to the high viscosity of the fuel that affects the rate of fuel flow to the combustion chamber. Such can be seen like the following figure 4 .

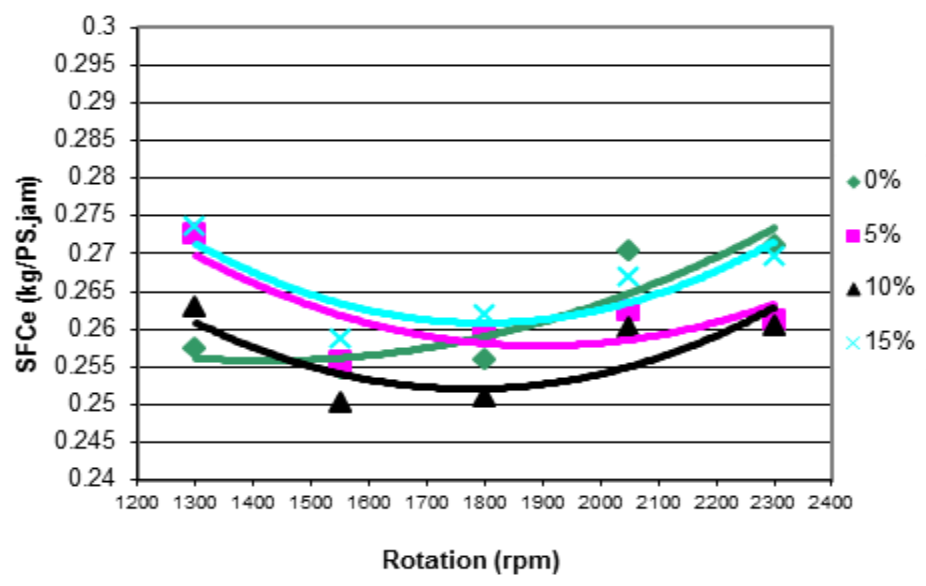

\section{Thermal efficiency}

Figure 4. Specific Fuel Consumption

The thermal efficiency obtained tends not to be too effected by the amount of used oil mixture in diesel fuel if the amount is not more than $10 \%$, this is due to the effective power produced tends to be the same as the use of pure diesel fuel. Such can be seen as the figure 5 . 


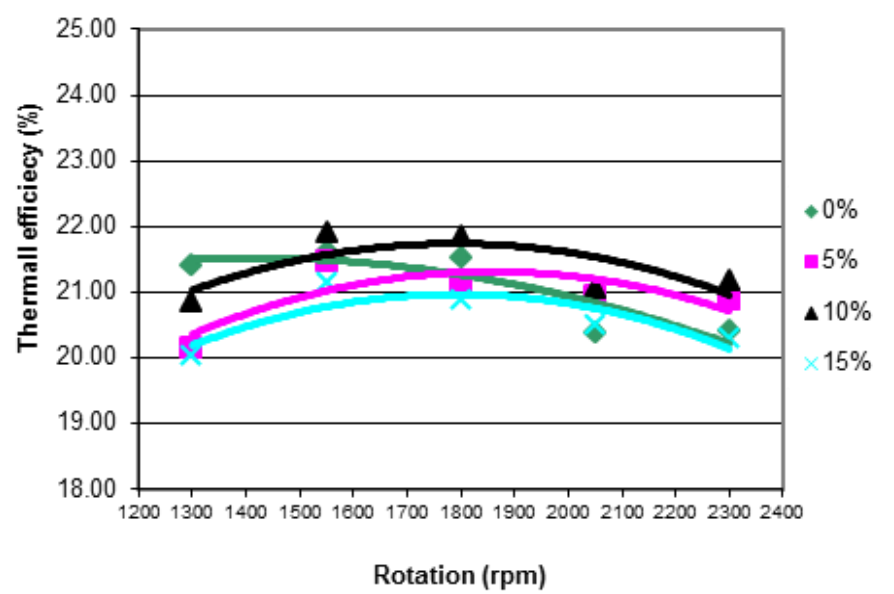

\section{CO2 Exhaust Gas}

Figure 5. Thermal efficiency

At low rotation, the exhaust gas of $\mathrm{CO} 2$ tends to be high because in this situation combustion is not yet perfect. But if the rotation continues to increase, $\mathrm{CO} 2$ will start to decrease. The mixture of used oil in diesel fuel increases the amount of CO2 in the flue gas. Such can be seen as the figure 6.

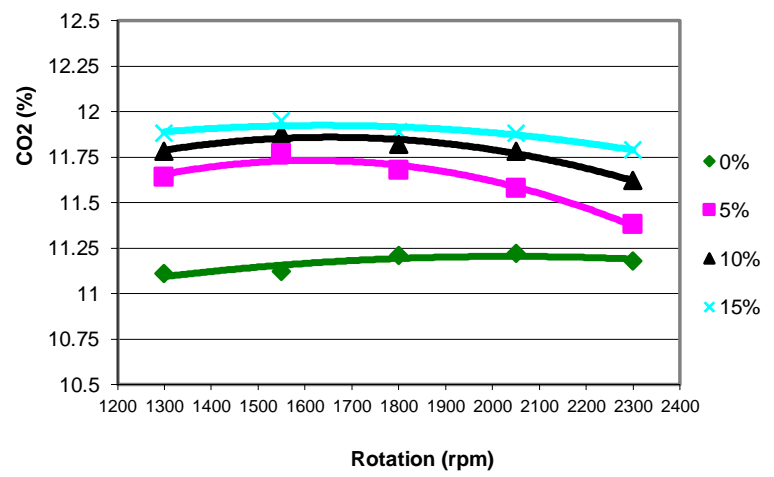

Figure 6. CO2 Emission

\section{Hydrocarbon (HC) Exhaust Gas}

The higher the engine speed, the amount of $\mathrm{HC}$ in the exhaust gas will increase. The addition of used oil in diesel fuel can increase HC in the disposed gas if the mixture exceeds $10 \%$. Such is shown in the following figure 7. 


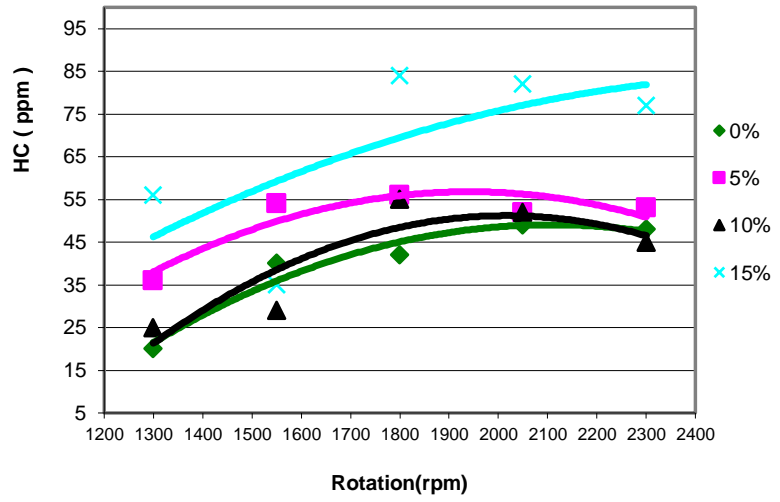

Figure 7. HC Emission

\section{Conclusion}

The process of filtering used oil by the method of adsorption and pyrolysis can improve the physical properties of used oil and clean the metal and dust that is in used oil. Adding used oil to diesel engine fuel can save fuel consumption and increase engine power, but gas emissions will increase if the percentage of used oil mixture in diesel is more than $10 \%$. With a mixture of up to $15 \%$ in addition to reducing engine power, gas emissions increase.

\section{Acknowledgment}

The authors wish to thanks the State Polythecnic Of Kupang and Department of Mechanical Engineering State Polythecnic Of Kupang

\section{References}

[1] Anonymous. http://www.detikoto.com. There are 70 million fake oils in Indonesia. 6 Februari 2009

[2] Raharjo W.P, 2007. Utilization of TEA (three ethyl amen) in the process of clarifying used oil as an ingredient fuel in aluminum smelting, Journal of Science \& Technology Research, 8 (2): $166-184$

[3] Arpa, O : Yumrutas, R ; Argunhan, Z. 2010. Experimental investigation of the effect of diesel like -fuel obtained from waste lubrication oil on engine performance and exhaust emission, Elsevier Journal fuel processing technology 91 : 1241-1249

[4] Arpa, O ; Yumrutas, R. 2009. Experimental investigation of gasoline like-fuel obtainet from waste lubrication oil of engine ferpormance and exhaust emission, Elsevier Journal fuel processing technology $91: 197-204$

[5] Prayitno, 1999. Study of the use of used oil as fuel oil, Proceedings of the national seminar basics and heat and mass transfer applications, Yogyakarta: 159-162 
[6] Beg. R.A. ; Sarker, M.R.I; Perves R. 2010. Production of diesel fuel from used engine oil, International Journal of Mechanical \& Mechatronis Engineering 10 ( 2 )

[7] EPA, 2008. Environmental Protection Agency, Used Oil Generated on Farm. Connecticut, US

[8] Mamiek M. , 2015. Analysis of Base Oil Adsorption and Pyrolysis Results on Used Oil. Journal of Mechanical Engineering PNK 2015.

[9] Rincon,J., Canizares, P. and Maria, T.G, 2007, Regeneration of used lubricant oil by ethane extraction,Journal of Supercritical Fluids, $39: 315-322$

[10] Darpopuspito. S, Brata T.I, 2005, Analysis of the Use of Kerosene and Oil Mix Fuels Lubricants Against Formation of Soot in Constant Turning Diesel Motor, Journal of Mechanical Engineering ITS, 5 (1): 1-6 